\title{
The role of Absorptive Capacity in the success of University-Firm Interaction in Brazil*
}

\author{
André Luiz da Silva Teixeira ${ }^{\dagger}$ \\ Márcia Siqueira Rapini ${ }^{\ddagger}$
}

\begin{abstract}
Resumo
O presente artigo analisa a capacidade de absorção (CA) das empresas como o principal determinante do sucesso destas na interação com universidades (IUE). Utilizando a CA como uma variável latente crescente aos tipos de sucesso em um modelo probit ordenado, os principais determinantes do sucesso da IUE estão associados com a CA potencial e uma maior aproximação entre as bases de conhecimento das empresas e universidades (e.g. relevância da ciência aplicada, o uso de publicações e relatórios, esforços internos em $P \& D$ ). Essa aproximação eleva a comunicação e o aprendizado, favorecendo o sucesso na IUE na perspectiva da empresa.
\end{abstract}

Palavras-chave: Capacidade de absorção, Interação, Universidade-Empresa, BR Survey

JEL: O31; L20

\section{Introduction}

Universities have relevant roles in fostering technological development of a country. They can act as an "antenna" capturing the knowledge of the technological frontier and providing it to firm to leverage its technological development (ALBUQUERQUE, 1999). Universities provide technological opportunities, labor-skilled workers, training, assistance, prototypes and also new companies (BRUNDENIUS; LUNDVALL; SUTZ, 2009; MOWERY; SAMPAT, 2006). In this sense, universities are considered an essential agent of Innovation System (NELSON; ROSENBERG, 1993). Their interaction with firms is an important activity of such system (EDQUIST, 2006), acting as knowledge diffuser, enhancing firms' chances to innovate, especially in product (ROBIN; SCHUBERT, 2013).

\footnotetext{
*This paper is a master thesis' outcome, funded by Coordination for the Improvement of Higher Education Personnel (CAPES, in Portuguese). We thank Professors Marcelo Pinho and Thiago Caliari for their previous comments; however both are exempt from liability for the opinions expressed in this paper.

${ }^{\dagger}$ PhD Student in Economics at Centre for Development and Regional Planning (CEDEPLAR/UFMG) and Professor at Federal University of Alfenas (UNIFAL). E-mail: andre.teixeira@unifal-mg.edu.br

$\ddagger$ Professor at Centre for Development and Regional Planning (CEDEPLAR/UFMG). E-mail: msrapini@cedeplar.ufmg.br
} 
For developing countries, such as Brazil, the university action is limited due to the lack of funding, pressures for higher education privatization, brain drain and low demand for senior workers (BRUNDENIUS; LUNDVALL; SUTZ, 2009). However, the universities have been considered important by innovative firms. According to the Brazilian Innovation Survey (PINTEC), the share of manufacturing innovative firms that consider universities as important sources of knowledge to innovate increased between 2006-2008 and 2012-2014 from $13.4 \%$ to $16.3 \%$. In addition, the share of these innovative firms that consider cooperation with universities (or research institutes) important to innovate also grew in this period: from $2.95 \%$ to $3.5 \%$ (IBGE, 2010, 2016).

At this context, this paper analyses two questions: (1) Can firms achieve their goals in this interaction?; (2) Do they have capacity for this? To answer both, we use the concept of Absorptive Capacity (AC), firstly defined by Cohen e Levinthal (1989) as a set of skills that enable the firm to value the new external knowledge, assimilate and exploit it commercially. This capability enables the firm to better evaluate external opportunities, to improve their results in cooperation with other agents (COHEN; LEVINTHAL, 1989), to learn in the interaction (LANE; LUBATKIN, 1998) and to be more innovative (MUROVEC; PRODAN, 2009; EBERS; MAURER, 2014).

So, there is evidence that the AC and its determinants may explain the success of university-firm interaction (UFI) in firms' perspective. This is the central hypothesis of this paper. To investigate its, the article is divided into six sections, besides this introduction. The second section presents the concept of $\mathrm{AC}$ and its dimensions. In the third section, the theoretical joint between AC and the success of UFI is carried out, building the hypotheses to be tested empirically by BR Survey database. Details about this database and econometric method used are in section 4 . In the fifth section, the results are discussed and the sixth section concludes.

\section{Absorptive Capacity: concepts and dimensions}

The first definition of Absorptive Capacity (AC) was from Cohen e Levinthal (1989, 1990) as a skill set that enables the firm to value the new external knowledge, assimilate it and apply it commercially. These skills allow firms to create new knowledge from a combination of external knowledge and firms' prior knowledge base. This capacity is cumulative and path dependent (COHEN; LEVINTHAL, 1990).

Lane e Lubatkin (1998) also consider AC as a learning ability. In the alliances context, these authors define $\mathrm{AC}$ as relative, because it depends on the similarities between partners related to the knowledge base, the ways to process this knowledge and the pursued objective.

Zahra e George (2002) redefine the AC as a set of organizational routines and processes, by which firms acquire, assimilate, transform and exploit external knowledge in

Econômica-Niterói, v. 20, n. 2, p. 7-32. Dezembro, 2018 
order to create an organizational dynamic capability to generate competitive advantages. As a dynamic capability, the development of AC should be aligned with firm's objectives - i.e. AC is a strategic decision of the firm (TEECE; PISANO; SHUEN, 1997) - and enhance firms' performance, creating competitive advantages.

Zahra e George (2002) suggest that the AC is composed by two dimensions: potential and realized AC. The potential AC provides a bigger flexibility to firms to undertake changes and reconfigure its operations. This capability is formed by the acquisition and assimilation capabilities. The former relates to firms' capability to recognize the value of the new external knowledge, to acquire and add it to firms' knowledge base. The second is equivalent to routines and procedures which enable the firm to analyze, process and interpret the external knowledge, given the previous knowledge (COHEN; LEVINTHAL, 1990; ZAHRA; GEORGE, 2002).

The realized AC reflects firms' capability to use the acquired knowledge to their goals, increasing its performance and creating competitive advantage (ZAHRA; GEORGE, 2002). This is composed by the transformation and exploitation dimensions. The first refers to firm's capability to develop and refine routines, facilitating the combination between old and new knowledge, this last already acquired and assimilated. The second capability refers to knowledge commercial application (COHEN; LEVINTHAL, 1990) and to routines and processes by which firms refine or create new competences (ZAHRA; GEORGE, 2002). Figure 1 summarizes these capabilities and their dimensions.

Figure 1 - Absorptive capacity's dimensions and their functions in the knowledge absorption process (Brazil, 2008-2009)

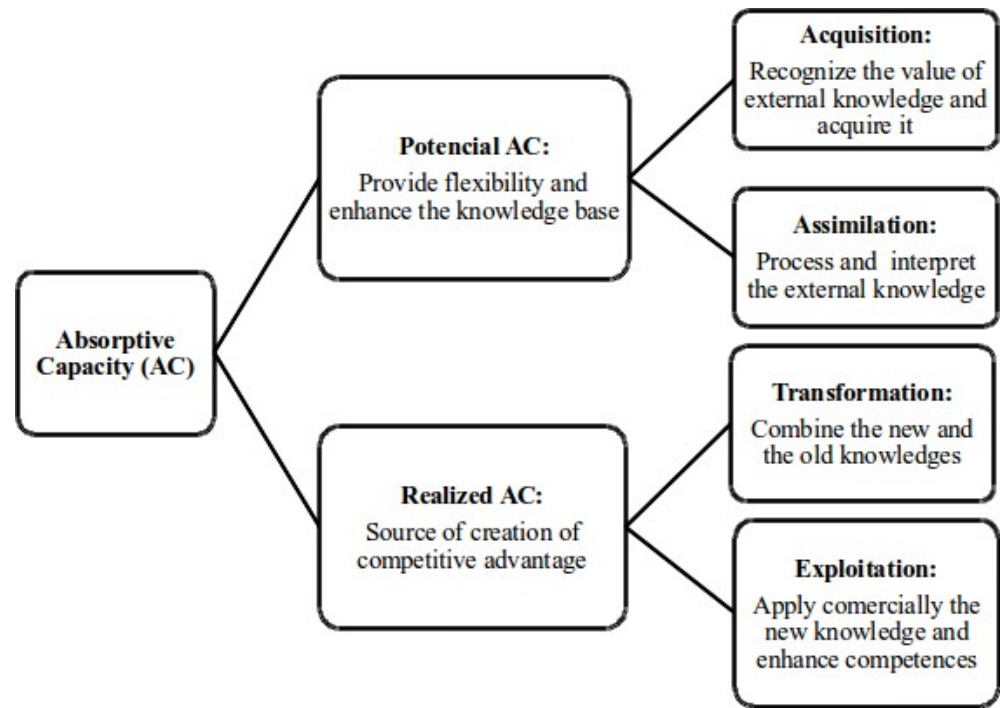

Fonte: Own elaboration based on Zahra e George (2002), Cohen e Levinthal (1990).

Given these dimensions and its functions, we can affirm that $\mathrm{AC}$ facilitates the iden- 
tification and evaluation of external opportunities (ENGELEN et al., 2014), reducing the uncertainty (COHEN; LEVINTHAL, 1990). Therefore, firms can also be more flexible (ZAHRA; GEORGE, 2002) and proactive, exploring the possible benefits of being the first mover, especially in turbulent markets (BOSCH; VOLBERDA; BOER, 1999). In addition, firms with greater AC have a higher innovative performance (ESCRIBANO; FOSFURI; TRIBÓ, 2009), innovating in product and process (EBERS; MAURER, 2014; MUROVEC; PRODAN, 2009).

In addition, the $\mathrm{AC}$ also affects interactions between firms and external agents such as universities. The development of AC allows firm to access new paradigms and to interact with more distant areas of knowledge (MEYER-KRAHMER; SCHMOCH, 1998), to learn more in partnership with other agents (LANE; LUBATKIN, 1998) and to get better results in these interactions (COHEN; LEVINTHAL, 1990), especially in the relationship with university scientists (FABRIZIO, 2009). The following section discusses the importance of $\mathrm{AC}$ in university-firm interaction context.

\section{Absorptive Capacity and University-Firm Interactions}

The importance of the knowledge generated in universities and research institutes for technology development has been recognized in the literature. Universities are sources of technological opportunities (KLEVORICK et al., 1995), skilled labor and they can participate in technological and scientific training networks (MOWERY; SAMPAT, 2006; NELSON; ROSENBERG, 1993).

However, this external knowledge will generate technological development only if firms develop internal capabilities to understand and apply its. In the present study, these internal capabilities are the Absorptive Capabilities (ACs) discussed above. AC is an important capability for catching-up countries (KIM, 1999).

The relationship between firm's AC and university-firm interaction (UFI) is not structured yet. This section discusses how AC and its determinants affect the success of UFI, developing hypotheses that will be tested econometrically in section 5 . These hypotheses are directly related to the database used ("BR Survey") that analyze many aspects about the UFI, but was not designed specifically to measure the AC and its determinants. However, this database allows the use of proxies to analyze them. Further details are described in section 4.1.

First, we consider that the success of UFI is affected by contextual or organizational factors. The contextual factors refer to the initial conditions of the relationship, such as reputation of the partners involved, previous links, geographical proximity, clear definition of objectives and the institutionalization degree of the relationship. The organizational factors are the degree of commitment, communication, trust, conflict and interdependence between partners (MORA-VALENTIN; MONTORO-SANCHEZ; GUERRAS-

Econômica-Niterói, v. 20, n. 2, p. 7-32. Dezembro, 2018 
MARTIN, 2004). Therefore, we analyze how AC and its determinants are related to these factors and, then, to the success of UFI in a firm's perspective ${ }^{1}$.

In general, firms with a bigger $\mathrm{AC}$ have more information about the knowledge generated outside (as in universities), allowing them to identify and to analyze accurately the relevant external knowledge and opportunities (COHEN; LEVINTHAL, 1990; ENGELEN et al., 2014). Thus, these firms can define more precisely the objectives pursued in UFI and the actions needed to absorb this external knowledge. In addition, these firms can identify the university resources that can be beneficial for them, allowing a greater interdependence between firm and universities, improving the chances of success (MORAVALENTIN; MONTORO-SANCHEZ; GUERRAS-MARTIN, 2004). Therefore, the development of AC would be a necessary condition to better define the objectives of the interaction and to establish a greater interdependence between universities and firms, enhancing chances of success in a UFI. In this way, factors that favor the AC's development will contribute for firm's success in an interaction with universities.

The first factor that improves the AC and the UFI's success is the labor qualification, especially graduated employees. Bruneel, D'Este e Salter (2010) found, but not discussed, that firms with a large share of employees with higher education tend to have a higher AC and thus face lower norms and cultures conflicts in UFI. These workers, especially those with Ph.D. degree, understand university culture and norms, reducing these barriers and conflicts, improving the UFI's chances of success. Furthermore, the reduction of conflict is favored by the clear definition of objectives (MORA-VALENTIN; MONTORO-SANCHEZ; GUERRAS-MARTIN, 2004). So, there is an indirect effect of qualified employees on the success in UFI by the improving AC and its effect on the objective definition.

Moreover, these workers can act as a gatekeeper (COHEN; LEVINTHAL, 1990), monitoring scientific and technological external knowledge, translating and bringing them to firms (KLEVORICK et al., 1995), increasing firms' knowledge base (ZAHRA; GEORGE, 2002) and approaching them to the knowledge base of universities, fostering the learning through interaction (LANE; LUBATKIN, 1998). So, these workers facilitate the access to external knowledge networks and the exchange of knowledge, concepts and ideas with scientists from other organizations such as universities (MANGEMATIN; NESTA, 1999). This communication favors the success of UFI (MORA-VALENTIN; MONTORO-SANCHEZ; GUERRAS-MARTIN, 2004). Thus, hiring graduate or postgraduate can strengthen the communication between universities and firms, raising firm's ability to absorb and learn from university knowledge, contributing to a clear definition of objective and a reduction of conflict, favoring the success of UFI.

\footnotetext{
${ }^{1}$ Mora-Valentin, Montoro-Sanchez e Guerras-Martin (2004) analyze the success of UFI in cooperation agreements. This type of interaction involves a bidirectional flow of information (FERNANDES et al., 2010). However, according to Lane e Lubatkin (1998), factors that determine a firm's capability to learn in a unidirectional relationship also affect the bidirectional learning channel, but with a different effect probably.
} 


\section{H1 - Hiring graduate or postgraduate favors the success in university-firms interac- tion.}

Another way to promote communication is through the temporary personnel exchange. According to Bloedon e Stokes (1994), the success of UFI depends on the trust gained in joint work and face-to-face contacts between firm's technicians and academic researchers. Both can be allowed by the temporary personnel exchange. This exchange facilitates, for firm's technicians, the access to university techniques, culture and norms, reducing interorganizational conflicts, promoting the success of UFI (MORA-VALENTIN; MONTORO-SANCHEZ; GUERRAS-MARTIN, 2004). This exchange act as a training for firms' employees, increasing the power of them to establish relationships, favoring the potential and realized AC (EBERS; MAURER, 2014). Moreover, this exchange can be a way to capture the university knowledge (tacit or codified) and to transfer to firm, acting as a gatekeeping, improving the AC (COHEN; LEVINTHAL, 1990). With a higher AC, the definition of the objective is clearer, increasing the chances of the success.

H2 - Temporary personnel exchange favors the success of university-firms interactions

AC is considered by Cohen e Levinthal (1990) as a "byproduct" from R\&D activities. These activities are sources of new knowledge (COHEN; LEVINTHAL, 1989) and a way to accumulate skills and expertise that favor firm's capabilities to absorb knowledge from universities (BISHOP; D'ESTE; NEELY, 2011). If the efforts in internal R\&D are greater, the proximity between knowledge bases of firms and universities is greater too (SCHMIDT, 2005). Moreover, the firms will be fittest to understand, evaluate and learn the external knowledge (LANE; LUBATKIN, 1998). Thereby, such closeness of knowledge bases will foster the communication between partners and boost the capacity to identify and exploit the university knowledge (FABRIZIO, 2009). Both aspects raise the chances of success.

$H 3$ - Greater efforts in $R \& D$ increase the chances of success in university-industry interaction.

H4 -Firms with R\&D department have higher chances of success in interaction with universities than firms that do not have it.

Publications and reports as a source of knowledge is another factor that approaches the knowledge bases. They provide general knowledge from a particular knowledge area. The understanding of this kind of knowledge by firms, places them in a better position to assess the relevance of this for their innovative activities (LANE; LUBATKIN, 1998). This ability to evaluate external knowledge composes the acquisition capability (COHEN; LEVINTHAL, 1990; ZAHRA; GEORGE, 2002). According to Vega-Jurado, GutiérrezGracia e Lucio (2008), firms that use this source of knowledge tend to have greater capacity to acquire and assimilate knowledge from universities and research institutes, adding these knowledge into their knowledge base, improving its. Thus, the learning capabilities and communication between firms and universities are strengthened (LANE; LU-

Econômica-Niterói, v. 20, n. 2, p. 7-32. Dezembro, 2018 
BATKIN, 1998), raising the chances of success.

H5 - Firms that use publications and reports as a source of knowledge from universities or research institutes have higher chances to achieve success in their interactions with these agents

The chances of success of UFI may vary according to science areas considered important by firms. The importance assigned to a particular area can indicate the potential use and the impact of advance in this area on firm's technological development (COHEN; LEVINTHAL, 1989). When firms give high importance to a knowledge area, it indicates that firms can identify greater potential uses of this knowledge, suggesting a better acquisition capability. This capability allows the firm to add this knowledge into its base (COHEN; LEVINTHAL, 1990), bringing it closer to the universities in this area. Therefore, the exchange of knowledge with researchers and firm's capability to learn through interactions increases (LANE; LUBATKIN, 1998), enhancing the chances of success in UFI. This impact is differentiated according to the area of science considered important because basic science provide a knowledge less applied to firms, if compared to applied science, requiring a greater learning and absorptive capacity from firm (COHEN; LEVINTHAL, 1990).

H6a - Firms that considered basic or applied science areas important have higher chances of success in interaction with universities or research institutes.

$H 6 b$ - The chances of success tend to be higher for firms that considered basic science important than those who considered applied science important

Until now, the determinants of UFI's success are associated mainly with Potential AC. The realized AC - the other dimension of AC - is related to competences enhancing (ZAHRA; GEORGE, 2002) and the commercial application of external knowledge (COHEN; LEVINTHAL, 1989). Firms that are able to implement innovations using knowledge generated in universities or research institutes tend to have higher realized AC (SCHMIDT, 2005). Therefore, firms have a better accuracy about the applicability of universities' knowledge, facilitating the definition, by firms, of goals to be pursued in UFI and what universities' resources is relevant for them. Therefore, firms that innovated and use universities or research institutes as sources of knowledge to innovate tend to have a greater realized $\mathrm{AC}$, and so a greater $\mathrm{AC}$, possessing higher chances to achieve success in UFI

H7 - Firms that innovated and used Universities or Research Institutes as a source of knowledge to innovate have higher chances to achieve success in the relationship with these agents than the other firms.

The figure 2 summarizes theses hypotheses tested empirically in the following section. 
Figure 2 - summarizes theses hypotheses tested empirically in the following section

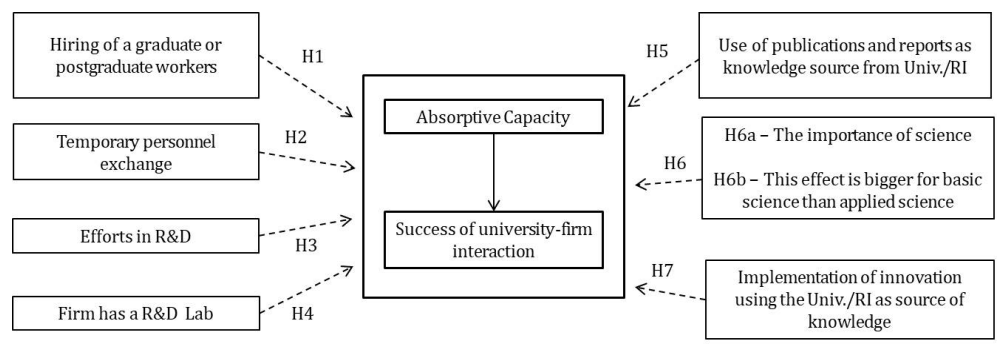

Fonte: Own elaboration.

Nota: Univ./RI is an abbreviation for University or Research Institutes.

\section{Methodology}

\subsection{Database: BR Survey}

The database used in this study come from a survey conducted in Brazil during 20082009 with research groups and firms, called "BR Survey". This survey departs from a database of research groups that declared interactions with the productive sector according to Census 2004 of Directory of the CNPq Research Groups. Details about this survey are in Fernandes et al. (2010). This paper focuses on firms' responses.

The firms' questionnaire investigates specific aspects of UFI and was based in Yale (KLEVORICK et al., 1995) and Carnegie Mellon Surveys (COHEN; NELSON; WALSH, 2002). In the end, 325 firms answered the questionnaire (19.5\% of total firms). This paper analyses firms from manufacturing, extractive or agriculture who answered the success of UFI and that employed at least one person. Thus, the sample was composed by 211 firms that interact with universities, $86.3 \%$ from manufacturing industry. This paper is the first initiative to measure $\mathrm{AC}$ and its determinants using BR Survey.

\subsection{Ordered Multinomial Models}

The ordered multinomial models are used when the dependent variable is a multinomialchoice and ordered variable. Cameron e Trivedi (2005) establish these models with an extension of the binary choice models in this way:

$$
y^{*}=x_{i} \beta+u_{i} \quad y_{i}=\text { ji if } \alpha_{j-1}<y_{i}^{*} \leq \alpha
$$

Where: $\mathrm{y}^{*}$ is the latent variable; $\mathrm{x}$ is the matrix of explanatory variable without the intercept; $\beta$ is the vector of coefficients; $\alpha j$ is the threshold for each alternative $\mathrm{j}$ of the 
dependent variable yi; ui is the error term that it is standard normal distributed (for ordered probit model).

The $\beta$ coefficients and the thresholds are estimated by maximizing a function of loglikelihood. This function is built by multiplication of all observations when the dependent variable is equal to $\mathrm{j}$ alternative for each $\mathrm{J}$. So, this model estimates $\mathrm{K}+\mathrm{J}-1$ parameters, where we have one threshold for each alternative and the $\mathrm{K}$ coefficients are the same for all alternatives and. The coefficient can be interpreted directly: if it is positive, the effect of a regressor on the latent variable is positive and the probability of a firm to choose the biggest alternative is higher (CAMERON; TRIVEDI, 2005). The next section details the variables.

\subsection{The building of variables}

\subsubsection{Dependent and latent variable}

Absorptive Capacity is multidimensional (ZAHRA; GEORGE, 2002), "fuzzy" (SCHMIDT, 2005) and difficult to measure directly, given its many intangibles aspects (EBERS; MAURER, 2014). Thus, AC has characteristics of a latent variable.

Some authors consider AC as latent in the use of some source of knowledge, considering that each type of knowledge requires a different AC (NEGRI, 2006; MUROVEC; PRODAN, 2009; SCHMIDT, 2005). Others use the spending on R\&D or related factors as proxy to AC (COHEN; LEVINTHAL, 1989; ESCRIBANO; FOSFURI; TRIBÓ, 2009; MANGEMATIN; NESTA, 1999), although the R\&D activities cannot be a good measure to AC (MOWERY; SAMPAT, 2006). Others developed a specific questionnaire for this purpose (EBERS; MAURER, 2014; ENGELEN et al., 2014; ROSA, 2013).

Here, AC is a latent variable to the firm's success in the UFI. Success is understood as the reach of the pursued objectives. Table 1 shows how this question was asked in BR Survey and how it is utilized here.

We consider the existence of four kinds of results - effective success, potential success, potential failure and effective failure - each one related with different levels of AC. It's supposed that firms that achieved success have the highest level of AC. As previously discussed, firms with higher AC tend to define their goals in a better way and, therefore, have greater chance to achieve their goals in UFI.

For the potential success or failure, it is understood that the firm has not achieved its goal or is still interacting. In this way, these firms can still develop their capabilities in the interaction, as suggested by Bishop, D'Este e Neely (2011), and had no evidence about the effectiveness of their actions to reach its objectives. Thus, AC tends to be lower than the AC of firms who have already achieved success. However, firms that think they will achieve success (potential success) tend to have higher AC than those who think they will not reach, because, when $\mathrm{AC}$ is greater, firms define their objectives in a better way and 
Table 1 - Dependent variable: success in university-firm interaction (Brazil, 2008-2009)

\begin{tabular}{lcccc}
\hline $\begin{array}{l}\text { In general, was successful the collaboration with universities } \\
\text { and research institutes to reach the expected objectives? }\end{array}$ & Value & Name \\
\hline A $\quad$ Yes, the collaboration has been successful to & 4 & Effective Success \\
reach firm's objectives until now & 3 & Potential Success \\
D $\quad \begin{array}{c}\text { The collaboration didn't finish, but I think } \\
\text { that the objectives will be achieved }\end{array}$ & 2 & Potential Failure \\
B $\quad \begin{array}{c}\text { The collaboration didn't finish, but I think } \\
\text { that the objectives will not be achieved } \\
\text { No, the collaboration hasn't been successful } \\
\text { to reach firm's objectives }\end{array}$ & 1 & Effective Failure \\
\hline
\end{tabular}

Fonte: Own elaboration based on BR Survey

they have better expectations about external knowledge (Cohen \& Levinthal, 1990).

Finally, about the difference between effective and potential success, it is understood that, in the first case, the internal firm's actions were effective to understand and use the external knowledge to their goal, meaning a higher firms' AC. In the second case, this does not happen and therefore firm's AC tends to be lower.

\subsubsection{Explanatory Variables}

Table 2 summarizes the explanatory and control variables. About firm size, larger firms tend to have higher capabilities to explore external knowledge sources and higher financial and human resources to build links between firms and universities (LAURSEN; SALTER, 2004). Since AC is intrinsically related to firm's ability to exploit external knowledge and that links facilitate the communication with the universities, bigger firms have greater chances of success.

The science based variable controls sectorial specificities. The aggregation was performed following Campos e Ruiz (2009) ${ }^{2}$, who identified science-based sectors as characterized by: higher technological intensity based in both internal and external sources of knowledge to innovate; emphasis on internal R\&D activities; diverse sources of learning, including UFI. Therefore, firms from this sector tend to have a higher AC and also higher chances to reach the effective success.

About motivations to interact, we consider reasons related to internal knowledge generation and a higher AC. The other reasons (make contact with students for future recruitment, the use of university resources, conduct tests and receive help in quality control) would be related to a lower AC because they focus only in the use of universities resources.

\footnotetext{
${ }^{2}$ They realized an adaptation of Pavitt's taxonomy to Brazilian context.
}

Econômica-Niterói, v. 20, n. 2, p. 7-32. Dezembro, 2018 


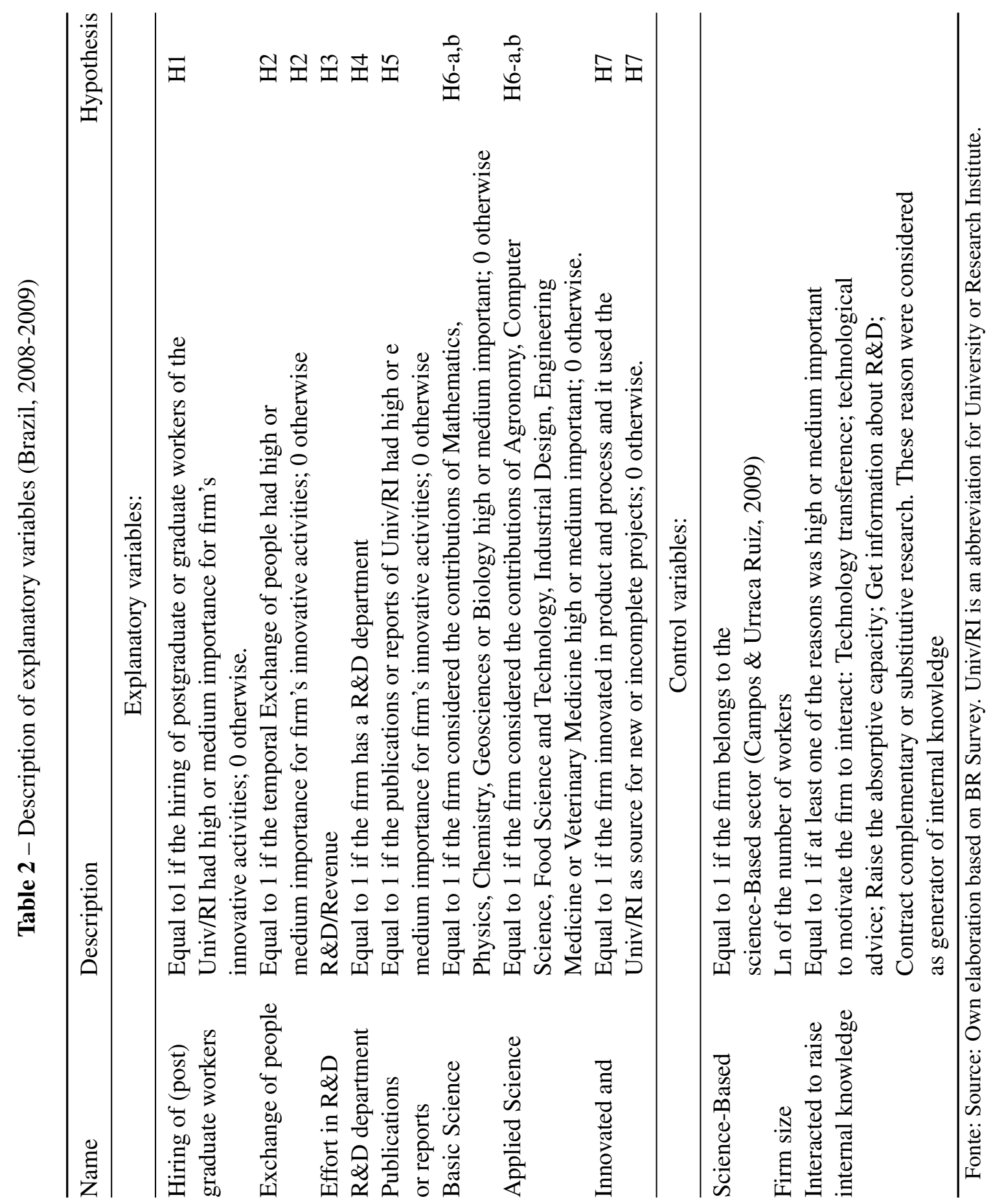


Finally, the variable "Firm that innovated and used the University or Institute of Research" is a proxy for AC realized. We considered two characteristics of AC: it is specific to each knowledge source (e.g. Negri (2006)) and it is related with both internal (process) and external (product) innovation (EBERS; MAURER, 2014) ${ }^{3}$. The idea is: when firms innovate and consider university/RI's knowledge relevant for this, they have higher capability to apply and exploit, in some way, this kind of knowledge; in other words, these firms have higher realized $\mathrm{AC}$ than other firms.

\section{Results}

This section tests the previous hypotheses. We first do a brief descriptive analysis of the database. Second, an econometric estimation is undertaken to test the hypothesis using an ordered probit model ${ }^{4}$. To facilitate the interpretation in the descriptive analysis, we consider only the success (effective and potential) and failure (potential and effective).

\subsection{Descriptive Analyses}

The database is composed by 211 firms: 19 had effective failure, 5 had potential failure, 64 had potential success and 123 had effective success. So, the success general rate is $88.63 \%$. Table 3 e 4 summarizes the information about the control and explanatory variables, respectively.

For table 3, it is expected that firm's size ${ }^{5}$ and the firm's focus into develop internal knowledge by UFI affect positively the chances of success. However, it is expected that firms from science-based sectors have less chances to achieve success than other or this difference is not significant.

For the explanatory variables, it is observed that the biggest differences in success rates are observed for applied science and for the use of publication or reports as knowledge source. About the last variable, the difference between firms that use this knowledge source and firms that don't use is 16 percentage points (pp). For applied science, the difference is $30.89 \mathrm{pp}$ while for basic science, this difference is only $8.32 \mathrm{pp}$. This may reflect the ease to learn and to absorb knowledge from applied sciences, as this one tends to be more similar to firm's knowledge base (COHEN; LEVINTHAL, 1990; LANE; LUBATKIN, 1998).

\footnotetext{
${ }^{3}$ In addition, we observe that $68 \%$ of innovative firms that used universities/RI as information source innovated both in product and process. To reduce variables, we use combined product and process innovation.

${ }^{4}$ We realized estimations by ordered logit model too. The results were similar and information criteria of Akaike and of Schwarz suggested the utilization of ordered probit model. The estimations by ordered logit model and these criteria are available upon request.

${ }^{5}$ We realized a $t$ test with different variances and the p-valor was 0,001 .
}

Econômica-Niterói, v. 20, n. 2, p. 7-32. Dezembro, 2018 
Small differences between successful and failed firms are observed for temporary personnel exchange (8.4pp), hiring (post) graduate (8.94pp), and among those who innovate and used universities/RI (3.9pp). Such small differences may suggest a low significance level or no significance to these in following models.

Finally, for R\&D activities, we observed that the average of $R \& D$ efforts is higher for firms that achieved success than for firms that did not achieve. This difference was statistically significant with $1 \%$ significance level ${ }^{6}$. On other hand, the success rate is slightly higher for those that do not have R\&D labs compared to those who have, which is divergent to the general expectation of a positive relationship between R\&D departments, $\mathrm{AC}$ and success of UFI.

Table 3 - Descriptive analyses of control variables (Brazil, 2008-2009)

\begin{tabular}{lcccccc}
\hline & $\begin{array}{c}\text { Number of } \\
\text { firms }\end{array}$ & Firm's size & \multicolumn{2}{c}{$\begin{array}{c}\text { Did the firm interact } \\
\text { to enhance the internal } \\
\text { knowledge? }\end{array}$} & $\begin{array}{c}\text { Science-Based } \\
\text { sectors }\end{array}$ & $\begin{array}{c}\text { Other } \\
\text { sectors }\end{array}$ \\
& & & & No & Yes & \\
\hline Failure (1) & 24 & 296.33 & 7 & 17 & 11 & 13 \\
Success (2) & 187 & 1669.23 & 11 & 176 & 64 & 123 \\
Total (3) (1+2) & 211 & & 18 & 193 & 75 & 136 \\
Success Rate & 88.63 & & 61.11 & 91.19 & 85.33 & 90.44 \\
$(\%)(2 / 3)$ & & & & & & \\
\hline
\end{tabular}

Fonte: Own elaboration based on BR Survey.

It is important to highlight that there is no evidence of strong multicollinearity in this model. Table 5 shows that VIF statistics were all lower than $2^{7}$. Table 6 and 7 show the econometric results.

For the control variables, only the sectorial specificity was not significant at $10 \%$. This result shows that, for Brazilian case, there is no significant difference between more technological sectors than others about the chances of success of UFI. About firm size, for each increase of $1 \%$ in the number of employees, the chances of achieving success effectively increase $4.5 \mathrm{pp}$ and decrease the chances of effectively failing to $1.4 \mathrm{pp}$. Thus, larger firms have more resources to establish links with universities and greater ability to exploit the knowledge arising from these. For the UFI reasons, firms that seek universities to develop internal knowledge has, on average, 21pp more chances to achieve effective success in the interaction with universities than other firms.

About $R \& D$ activities, $R \& D$ efforts and $R \& D$ department exert distinct influences on the $\mathrm{AC}$ and in the chances of success. The $\mathrm{R} \& \mathrm{D}$ efforts were significant statistically at $1 \%$. If the ratio between $R \& D$ spending and revenue increases $1 \mathrm{pp}$, the chances to achieve

\footnotetext{
${ }^{6}$ We realized a t test with different variances.

${ }^{7}$ These statistics was obtained from a linear regression model.
} 
effective success increase, on average, by $1.3 \mathrm{pp}$ and the chances of failure effectively reduce by $0.4 \mathrm{pp}$. These results lead us to not reject the hypothesis 3 .

However, the importance of $R \& D$ department was the opposite of literature expectations. It was expected that having a R\&D department would raise the AC (MANGEMATIN; NESTA, 1999; SCHMIDT, 2005). Although, firm with R\&D labs has, on average, $14.3 \mathrm{pp}$ less chances in achieving success effectively vis-a-vis firms that do not have it, while this probability is 4pp higher to effective failure. Despite this variable was significant only at $10 \%$, this result implies important reflections.

A possible explanation is related to organizational aspects not captured in this study. The development of AC requires the existence of interfaces between firm's departments to disseminate the external knowledge (COHEN; LEVINTHAL, 1990; ZAHRA; GEORGE, 2002). Bosch, Volberda e Boer (1999), for example, argue that hierarchical forms of organization tend to affect negatively the development of AC because they limit the scope of knowledge to be absorbed and firm's flexibility to this. Thus, the negative effect of R\&D department can indicate that firms on sample, on average, have hierarchical internal structures with low participation of employees from other areas in R\&D activities, which hinders the diffusion of knowledge internally. Firms' R\&D department may be "isolated" from other firms' areas, making it difficult to generate the AC, reducing the chances of success of the UFI.

Another aspect related to the closeness of knowledge bases is the use of publications and reports. Firms that consider important these sources of knowledge from universities/RI tend to have greater capability to assess the importance of knowledge from these sources and assimilate it, having a higher potential AC (VEGA-JURADO; GUTIÉRREZGRACIA; LUCIO, 2008). Thus, these firms incorporate this knowledge at its base, facilitating learning and knowledge exchange between parties (LANE; LUBATKIN, 1998), raising the chances of success compared to firms that do not use these sources. Here, this difference is $18.1 \mathrm{pp}$ for effective success. So, hypothesis 5 is not rejected.

About science, it was observed that only the use of applied sciences had a positive and significant impact on the success of UFI. In terms of marginal effects, the probability of effective success is, on average, 23pp higher for firms that considered applied science important when compared with other companies. This result suggests that firms in the sample have higher capability to acquire knowledge from the applied sciences than from basic sciences. The absorption of knowledge from applied sciences is easier than the ones from basic sciences, because the knowledge generated by the first area is more similar to those generated in firms, facilitating learning (COHEN; LEVINTHAL, 1990; LANE; LUBATKIN, 1998), and increasing the chances of success.

But this result has a limitation. Of 211 companies, $44.1 \%$ considered both type of sciences important, $3.3 \%$ considered only basic science and $43.6 \%$ only applied science. Thus, the "basic science" variable represent, in large part, firms that considered both areas important. The significance of "applied science" is mainly related to the firms that

Econômica-Niterói, v. 20, n. 2, p. 7-32. Dezembro, 2018 
only have considered this important area, enhancing its effect. This suggest a strong intertwining between these areas and the difficulty to separate them (Nelson \& Rosenberg 1993).

For the hypotheses 1 and 2, while hiring graduate or postgraduate was not statistically significant, the temporary personnel exchange was at $10 \%$. In terms of marginal effects, firms that carry out personal exchange have $12.9 \mathrm{pp}$ more chances to reach the effective success in comparison with other firms. Thus, at least in $10 \%$, there is no evidence to reject the hypothesis 3 , while hypothesis 2 is rejected.

This result shows the importance of face-to-face contact for AC and the success of UFI. While the hiring of (post) graduate can raise the AC and allow a better communication between universities and firms (COHEN; LEVINTHAL, 1990; LANE; LUBATKIN, 1998; MANGEMATIN; NESTA, 1999), this does not allow directly the face-to-face contact between university researchers and firms workers, as the temporary personnel exchange does. This exchange favors the realization of joint projects and the access to university culture and norms by firms' employees, reducing inter-organizational conflicts and acting as "training" for employees, increasing their abilities to establish relationships and to be gatekeepers. These factors together increase the AC and the chances of success.

However, this result should not be understood as the irrelevance of labor qualifications for the AC and UFI success. The individual skills of workers are important determinants of AC, particularly workers with higher degree (NEGRI, 2006; SCHMIDT, 2005). These workers help to reduce barriers relate to differences in norms and cultures inherent to UFI (BRUNEEL; D'ESTE; SALTER, 2010) and favor communication between agents (MANGEMATIN; NESTA, 1999). It is possible that the variable "hiring workers with higher education" failed to capture these effects of this skill of labor. This is one of the limitations of this study.

Finally, there was no statistical difference between the chances of success for firms that innovated and used universities or research institutes as a source of information for their projects vis a vis other firms. Therefore, the realized AC was not decisive for the success of UFI.

Thus, despite the database limitations, it was possible to show econometrically how the $\mathrm{AC}$ and its determinants are related to the success of UFI. It was observed that the main AC determinants are associated with potential AC, the generation of knowledge internally and similarities between knowledge bases (e.g. R\&D efforts and the use of publication/reports). Figure 3 summarizes the results discussed.

\section{Final remarks}

The main purpose of this paper was to relate, in a theoretical and empirical way, the absorptive capacity (AC), its dimensions and determinants, with the success of university- 
Figure 3 - Absorptive capacity and the success of UFI: main determinants (Brazil, 2008-2009)

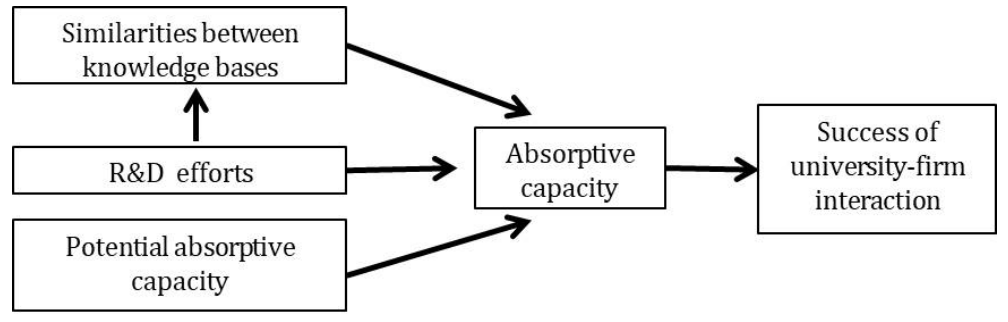

Fonte: Authors' elaboration

firm interaction (UFI) in a firm's perspective. This objective came from the growing importance of universities to the firms' innovative process and to fill the theoretical gap left by Rosa (2013). The comprehension of the relationship between AC and UFI's success becomes important especially in developing countries like Brazil. In this context, the UFI is a way to complement or substitute the firms' R\&D (RAPINI et al., 2009) and to diffusion the knowledge from the frontier, captured by universities (ALBUQUERQUE, 1999).

As we discussed, the AC is a necessary condition for firms to achieve the objectives in this interaction with universities. A better internal AC permits firms to identify and to analyze more accurately the knowledge from universities (COHEN; LEVINTHAL, 1990; ENGELEN et al., 2014), allowing them to define more precisely the objectives pursued in this interaction. This capability also lets firms to identify the university's resources beneficial for them, allowing a greater interdependence between the firm and the universities. This interdependence and the better definition of objective improve the chances of success (MORA-VALENTIN; MONTORO-SANCHEZ; GUERRAS-MARTIN, 2004).

In this paper, we infer how dimensions and determinants of AC may favor the success of UFI. Given the theoretical discussion and AC as a nebulous concept (SCHMIDT, 2005) and difficult to measure directly (EBERS; MAURER, 2014), this capacity was used as a latent variable to the UFI's success in a ordered probit model. We considered four types of success in increasing order of AC: effective failure; potential failure; potential success; effective success.

It was observed that the main determinants of this success were related with the generation of internal knowledge by firms and the similarities between the knowledge bases of universities and firms. When the partners' knowledge bases are similar, the relative $\mathrm{AC}$, the ease of communication and learning are greater (LANE; LUBATKIN, 1998), and the probability of success too. These determinants are: efforts in R\&D; importance of applied science; use of publications and reports of universities/RI as knowledge source. These determinants are associated with Potential AC, especially the last.

Differently to the potential AC's aspects, the proxy for realized AC was not significant.

Econômica-Niterói, v. 20, n. 2, p. 7-32. Dezembro, 2018 
Hence, the firm's capability to obtain competitive advantage from the external knowledge (ZAHRA; GEORGE, 2002) was not relevant to explain the success of UFI while the firm's capability to acquire and assimilate this knowledge was relevant. This result is limited because we did not estimate AC using a specific measure, as Ebers e Maurer (2014) and Rosa (2013) did.

Two results were unexpected: (1) Negative relationship between UFI's success and R\&D department; (2) No significance for hiring graduate or postgraduate. The first can be explained because the impossibility to capture the effect of organizational aspects of AC, like intra-firm organization, suggesting the necessity of specific studies that relate firms' organizational aspects with the AC generation, especially in UFI context.

The second can be explained by three reasons. First of all, the better communication, which would be provided by the (post)graduate hired, was favored directly by the temporary personnel exchange or indirectly by the similarities of knowledge bases of firms and universities. These similarities were boosted by R\&D efforts and the use of publications and reports. The second explanation reveal the main limitation of this paper: the variable "hiring of (post) graduate workers" fails to capture the effect of employees with higher education on the AC and the success of UFI. The BR Survey database did not permit the use of a more appropriated variable, as "percent of postgraduate employees". The third possible explanation is: the database is composed by firms that already interact, which have bigger AC than non-interactive firms, and, so, these workers could be less important.

Moreover, these two unexpected results can be explained by the uneven complexity of university-firm interaction. This complexity suggests the necessity of more specific and detailed studies, like case studies or specific questionnaires, to relate AC - its dimensions and determinants - with UFI.

Despite these limitations, it was observed the importance of the development of internal capabilities by firms to achieve their success in the UFI. This understanding becomes crucial in developing countries, such as Brazil, where the universities and their proximity to firms are important to catch-up. Although universities may bring the frontier knowledge to the country (ALBUQUERQUE, 1999), firms must develop internal capabilities to identify and assimilate the knowledge provided by universities. In other words, the contribution of universities for catching-up process will be greater when firms develop more internal absorptive capacity, especially the potential AC.

\footnotetext{
Abstract

This paper analyzes the firm's absorptive capacity (AC) as the main determinant of its success in an interaction with university (UFI). Using $\mathrm{AC}$ as a growing latent variable to the types of success in an ordered probit model, the main determinants of this success are associated with potential AC or closeness of knowledge bases of firms and universities (e.g. relevance of applied science, use of publications and reports, internal $\mathrm{R} \& \mathrm{D}$ efforts). This proximity improves the communication
} 
and learning, favoring the success of UFI in a firm's perspective.

Keywords: Absorptive Capacity, University-firm interaction, BR Survey.

JEL: O31; L20

\section{References}

ALBUQUERQUE, E. M. National systems of innovation and Non-OECD countries: notes about a rudimentary and tentative 'typology. Brazilian Journal of Political Economy, v. 19, n. 4, p. 35-52, 1999.

BISHOP, K.; D'ESTE, P.; NEELY, A. Gaining from interactions with universities: Multiple methods for nurturing absorptive capacity. Research Policy, v. 40, n. 1, p. 30-40, 2011.

BLOEDON, R. V.; STOKES, D. R. Making University/Industry Collaborative Research Succeed. Research-Technology Management, Taylor \& Francis, v. 37, n. 2, p. 44-48, 3 1994. Disponível em: <https://www.tandfonline.com/doi/full/10.1080/08956308.1994. 11670969>.

BOSCH, F. A. J. V. d.; VOLBERDA, H. W.; BOER, M. d. Coevolution of Firm Absorptive Capacity and Knowledge Environment: Organizational Forms and Combinative Capabilities. Organization Science, v. 10, n. 5, p. 551-568, 1999. Disponível em: <https://www.jstor.org/stable/2640317>.

BRUNDENIUS, C.; LUNDVALL, B.-å.; SUTZ, J. The Role of Universities in Innovation Systems in Developing Countries: Developmental University Systems - Empirical, Analytical and Normative Perspectives. In: LUNDVALL, B.-Å. et al. (Ed.). Handbook of Innovation Systems and Developing Countries: building domestic capabilities in a global setting. Cheltenham: Edward Elgar Publishing, 2009. cap. 11. ISBN 9781847206091.

BRUNEEL, J.; D'ESTE, P.; SALTER, A. Investigating the factors that diminish the barriers to university-industry collaboration. Research Policy, v. 39, n. 7, p. 858-868, 2010. Disponível em: <https://www.sciencedirect.com/journal/research-policy/vol/39/ issue/7>.

CAMERON, A. C.; TRIVEDI, P. K. Microeconometrics: methods and applications. 1. ed. New York: Cambridge University Press, 2005. 1034 p. ISBN 0521848059.

Econômica-Niterói, v. 20, n. 2, p. 7-32. Dezembro, 2018 
CAMPOS, B.; RUIZ, A. U. Padrões Setoriais de Inovação na Indústria Brasileira. Revista Brasileira de Inovação, v. 8, n. 1, p. 167-210, 10 2009. Disponível em: $<$ https://periodicos.sbu.unicamp.br/ojs/index.php/rbi/article/view/8648978>.

COHEN, W. M.; LEVINTHAL, D. A. Innovation and Learning: The Two Faces of R \&amp; D. The Economic Journal, WileyRoyal Economic Society, v. 99, n. 397, p. 569, 9 1989. ISSN 00130133. Disponível em: <https://www.jstor.org/stable/2233763?origin= crossref>.

COHEN, W. M.; LEVINTHAL, D. A. Absorptive Capacity: A New Perspective on Learning and Innovation. Administrative Science Quarterly, Sage Publications, Inc.Johnson Graduate School of Management, Cornell University, v. 35, n. 1, p. 128, 3 1990. ISSN 00018392. Disponível em: <https://www.jstor.org/stable/2393553?origin= crossref $>$.

COHEN, W. M.; NELSON, R. R.; WALSH, J. P. Links and Impacts: The Influence of Public Research on Industrial R\&amp;D. Management Science, INFORMS, v. 48, n. 1, p. 1-23, 1 2002. Disponível em: <http://pubsonline.informs.org/doi/abs/10.1287/mnsc. 48.1.1.14273>.

EBERS, M.; MAURER, I. Connections count: How relational embeddedness and relational empowerment foster absorptive capacity. Research Policy, v. 43, n. 2, p. 318-332, 3 2014. Disponível em: <https://linkinghub.elsevier.com/retrieve/pii/ S0048733313001960>.

EDQUIST, C. Systems of Innovation: Perspectives and Challenges. In: FARGERBERG, J.; MOWERY, D.; NELSON, R. (Ed.). The Oxford handbook of innovation. New York: Oxford University Press, 2006. p. 181-208. Disponível em: <http://oxfordhandbooks. com/view/10.1093/oxfordhb/9780199286805.001.0001/oxfordhb-9780199286805-e-7>.

ENGELEN, A. et al. Entrepreneurial orientation in turbulent environments: The moderating role of absorptive capacity. Research Policy, v. 43, n. 8, p. 13531369, 10 2014. Disponível em: <https://linkinghub.elsevier.com/retrieve/pii/ S0048733314000419>.

ESCRIBANO, A.; FOSFURI, A.; TRIBÓ, J. A. Managing external knowledge flows: The moderating role of absorptive capacity. Research Policy, North-Holland, v. 38, n. 1, p. 96-105, 2 2009. Disponível em: <https://www.sciencedirect.com/science/article/abs/ pii/S0048733308002357>.

FABRIZIO, K. R. Absorptive capacity and the search for innovation. Research Policy, North-Holland, v. 38, n. 2, p. 255-267, 3 2009. Disponível em: <https: //www.sciencedirect.com/science/article/abs/pii/S0048733308002771>. 
FERNANDES, A. C. et al. Academy-industry links in Brazil: evidence about channels and benefits for firms and researchers. Science and Public Policy, Oxford University Press, v. 37, n. 7, p. 485-498, 8 2010. Disponível em: $<$ https://academic.oup.com/spp/article-lookup/doi/10.3152/030234210X512016>.

IBGE. Pesquisa de Inovação Tecnológica 2008. Rio de Janeiro, 2010.

IBGE. Pesquisa Industrial de Inovação Tecnológica - PINTEC 2014. Rio de Janeiro, 2016.

KIM, L. Building technological capability for industrialization: analytical frameworks and Korea's experience. Industrial and Corporate Change, Oxford University Press, v. 8, n. 1, p. 111-136, 3 1999. Disponível em: <https://academic.oup.com/icc/article-lookup/ doi/10.1093/icc/8.1.111>.

KLEVORICK, A. K. et al. On the sources and significance of interindustry differences in technological opportunities. Research Policy, North-Holland, v. 24, n. 2, p. 185-205, 3 1995. Disponível em: <https://www.sciencedirect.com/science/article/pii/ $004873339300762 \mathrm{I}>$.

LANE, P. J.; LUBATKIN, M. Relative absorptive capacity and interorganizational learning. Strategic Management Journal, Wiley-Blackwell, v. 19, n. 5, p. 461-477, 5 1998. Disponível em: <http://doi.wiley.com/10.1002^\%28SICI \%291097-0266। $\% 28199805 \backslash \% 2919 \backslash \% 3 \mathrm{~A} 5 \backslash \% 3 \mathrm{C} 461 \backslash \% 3 \mathrm{~A} \backslash \% 3 \mathrm{AAID}-\mathrm{SMJ} 953 \backslash \% 3 \mathrm{E} 3.0 . \mathrm{CO} \% 3 \mathrm{~B} 2-\mathrm{L}>$.

LAURSEN, K.; SALTER, A. Searching high and low: what types of firms use universities as a source of innovation? Research Policy, North-Holland, v. 33, n. 8, p. 1201-1215, 10 2004. ISSN 0048-7333. Disponível em: <https: //www.sciencedirect.com/science/article/abs/pii/S0048733304001003>.

MANGEMATIN, V.; NESTA, L. What kind of knowledge can a firm absorb? International Journal of Technology Management, v. 18, n. 3/4, p. 149, 1999. Disponível em: <http://www.inderscience.com/link.php?id=2771>.

MEYER-KRAHMER, F.; SCHMOCH, U. Science-based technologies: university-industry interactions in four fields. Research Policy, v. 27, n. 8, p. 835-851, 12 1998. ISSN 00487333. Disponível em: <http://linkinghub.elsevier.com/retrieve/pii/S0048733398000948>.

MORA-VALENTIN, E. M.; MONTORO-SANCHEZ, A.; GUERRAS-MARTIN, L. A. Determining factors in the success of R\&amp;D cooperative agreements between firms and research organizations. Research Policy, v. 33, n. 1, p. 17-40, 1 2004. ISSN 00487333. Disponível em: <http://linkinghub.elsevier.com/retrieve/pii/ S0048733303000878>. 
MOWERY, D. C.; SAMPAT, B. N. Universities in National Innovation Systems. In: FAGERBERG, J.; MOWERY, D. C.; NELSON, R. R. (Ed.). The Handbook of innovation. Oxford University Press, 2006. Disponível em: <http://oxfordhandbooks. com/view/10.1093/oxfordhb/9780199286805.001.0001/oxfordhb-9780199286805-e-8>.

MUROVEC, N.; PRODAN, I. Absorptive capacity, its determinants, and influence on innovation output: Cross-cultural validation of the structural model. Technovation, v. 29, n. 12, p. 859-872, 12 2009. Disponível em: <http://linkinghub.elsevier.com/retrieve/pii/ S0166497209000844>.

NEGRI, F. D. Determinantes da capacidade de absorção das firmas brasileiras: qual a influência do perfil da mão-de-obra. In: NEGRI, J. A. D.; NEGRI, F. D.; COELHO, D. (Ed.). Tecnologia, Exportação e Emprego. Brasília: Instituto de Pesquisa Econômica Aplicada, 2006. p. 101-122.

NELSON, R.; ROSENBERG, N. Technical Innovation and National Systems. In: National Innovation Systems: A Comparative Analysis. New York: Oxford University Press, 1993. p. 3-21.

RAPINI, M. S. et al. University-industry interactions in an immature system of innovation: evidence from Minas Gerais, Brazil. Science and Public Policy, Oxford University Press, v. 36, n. 5, p. 373-386, 6 2009. Disponível em: <https://academic.oup.com/spp/article-lookup/doi/10.3152/030234209X442016>.

ROBIN, S.; SCHUBERT, T. Cooperation with public research institutions and success in innovation: Evidence from France and Germany. Research Policy, Elsevier, v. 42, n. 1, p. 149-166, 2 2013. Disponível em: <http://linkinghub.elsevier.com/retrieve/pii/ S0048733312001515>.

ROSA, A. C. Capacidade absortiva de empresas que possuem interação com universidades. Tese (Doutorado) - Universidade do Vale do Rio dos Sinos, 2013.

SCHMIDT, T. Absorptive Capacity: One Size Fits All? Firm-level Analysis of Absorptive Capacity for Different Kinds of Knowledge. ZEW Discussion Papers, ZEW - Zentrum für Europäische Wirtschaftsforschung / Center for European Economic Research, 2005. Disponível em: <https://ideas.repec.org/p/zbw/zewdip/4555.html>.

TEECE, D. J.; PISANO, G.; SHUEN, A. Dynamic Capabilities and Strategic Management. Strategic Management Journal, Wiley, v. 18, n. 7, p. 509-533, 1997. Disponível em: <https://www.jstor.org/stable/3088148>.

VEGA-JURADO, J.; GUTIÉRREZ-GRACIA, A.; LUCIO, I. Fernández-de. Analyzing the determinants of firm's absorptive capacity: beyond R\&amp;D. $R \& D$ Management, Wiley/Blackwell (10.1111), v. 38, n. 4, p. 392-405, 9 2008. Disponível em: $<$ http://doi.wiley.com/10.1111/j.1467-9310.2008.00525.x>. 
ZAHRA, S. A.; GEORGE, G. Absorptive Capacity: A Review, Reconceptualization, and Extension. The Academy of Management Review, Academy of Management, v. 27, n. 2, p. 185, 4 2002. Disponível em: <http://links.jstor.org/sici?sici=0363-7425\\%28200204। $\% 2927 \backslash \% 3 \mathrm{~A} 2 \backslash \% 3 \mathrm{C} 185 \backslash \% 3 \mathrm{AACARRA} \% 3 \mathrm{E} 2.0 . \mathrm{CO} \% 3 \mathrm{~B} 2-6 \&$ origin=crossref $>$. 
Table 4 - Descriptive analyses of explanatory variables (Brazil, 2008-2009)

\begin{tabular}{|c|c|c|c|c|c|c|}
\hline $\mathrm{H}$ & $\begin{array}{l}\text { Number of firms according to } \\
\text { the answer }\end{array}$ & & Failure (1) & Success (2) & $\begin{array}{c}\text { Total (3) } \\
(1+2)\end{array}$ & $\begin{array}{l}\text { Success rate } \\
(\%)(2 / 3)\end{array}$ \\
\hline \multirow[t]{2}{*}{$\mathrm{H} 1$} & Was the hiring graduate or & No & 12 & 57 & 69 & 82.61 \\
\hline & & Yes & 12 & 130 & 142 & 91.55 \\
\hline \multirow[t]{2}{*}{$\mathrm{H} 2$} & Was temporal personnel & No & 18 & 102 & 120 & 85.00 \\
\hline & & Yes & 6 & 85 & 91 & 93.41 \\
\hline H3 & $\begin{array}{l}\text { Average of efforts } \\
\text { in } R \& D(\%)\end{array}$ & & 2846 & 5452 & & \\
\hline \multirow[t]{2}{*}{$\mathrm{H} 4$} & Does firm have a R\&D & No & 6 & 51 & 57 & 89.47 \\
\hline & & Yes & 18 & 136 & 154 & 88.31 \\
\hline \multirow[t]{2}{*}{ H5 } & Were publications or reports & No & 12 & 39 & 51 & 76.47 \\
\hline & & Yes & 12 & 148 & 160 & 92.50 \\
\hline \multirow[t]{4}{*}{ H6 } & Was Basic Science important? & No & 17 & 94 & 111 & 84.68 \\
\hline & & Yes & 7 & 93 & 100 & 93.00 \\
\hline & Was Applied Science important? & No & 10 & 16 & 26 & 61.54 \\
\hline & & Yes & 14 & 171 & 185 & 92.43 \\
\hline \multirow[t]{3}{*}{$\mathrm{H} 7$} & Did the firm innovate and use & No & 14 & 91 & 105 & 86.67 \\
\hline & & Yes & 10 & 96 & 106 & 90.57 \\
\hline & Success or failure & & 24 & 187 & 211 & 88.63 \\
\hline
\end{tabular}

Fonte: Own elaboration based on BR Survey.

Nota: $H$ is an abbreviation for hypothesis; Univ./RI is an abbreviation for Universities or Research Institute. 
Table 5 - Variance inflation factor (VIF) (Brazil, 2008-2009)

\begin{tabular}{lc}
\hline Variable & VIF \\
\hline Hiring of (post) graduate workers & 1.47 \\
Firm size & 1.41 \\
Exchange of people & 1.31 \\
R\&D department & 1.29 \\
Efforts in R\&D & 1.27 \\
Publications and reports & 1.24 \\
Science-Based & 1.2 \\
Innovated and used the Univ/RI & 1.17 \\
Applied Science & 1.16 \\
Interacted to raise internal knowledge & 1.09 \\
Basic Science & 1.08 \\
\hline Average & 1.24 \\
\hline \multicolumn{2}{l}{ Fonte: Own elaboration based on BR Survey. } \\
Nota: Univ/RI is acronym to Universities or \\
Research Institute.
\end{tabular}

Econômica-Niterói, v. 20, n. 2, p. 7-32. Dezembro, 2018 


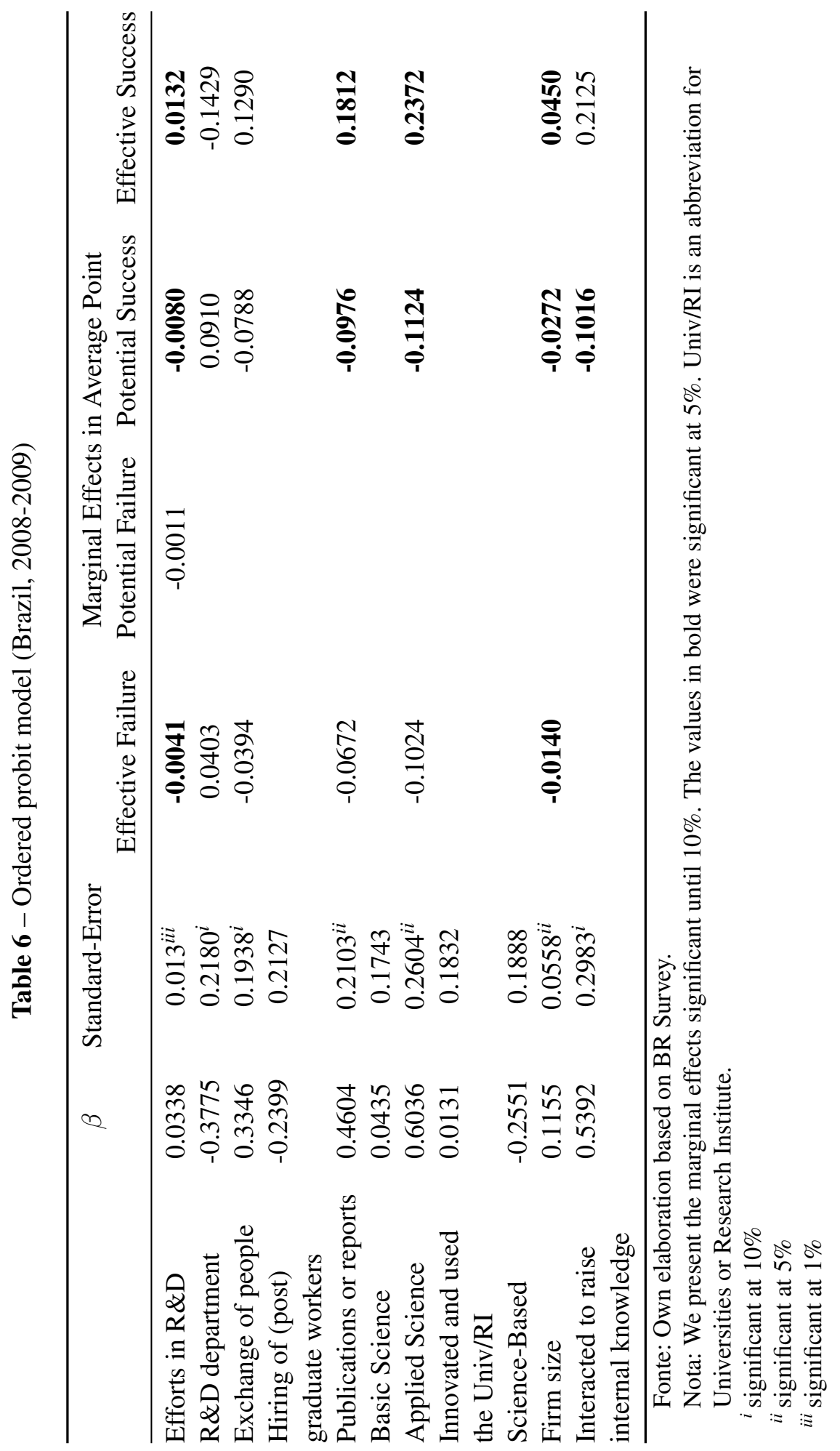

Econômica-Niterói, v. 20, n. 2, p. 7-32. Dezembro, 2018 
Table 7 - Threshold of each type of success (Brazil, 2008-2009)

\begin{tabular}{lc} 
Effective Failure & $\begin{array}{c}\text { Interval of each type of success } \\
(-\infty, 0.2797)\end{array}$ \\
Potential Failure & $(0.2797,0.4451)$ \\
Potential Success & $(0.4451,1.6031)$ \\
Effective Success & $(1.6031,+\infty)$ \\
\hline
\end{tabular}

Fonte: Own elaboration based on BR Survey. 